\title{
Pengaruh Perhatian Orangtua dalam Pembelajaran daring terhadap Motivasi Belajar Peserta Didik Madrasah Tsanawiyah
}

\author{
Maptuhah $^{1}$, Juhji $^{2}$ \\ Universitas Islam Negeri Sultan Maulana Hasanuddin Banten \\ e-mail: maftuah8970@gmail.com,juhji@uinbanten.ac.id \\ Submitted: 09-05-2021 Revised : 15-06-2021 Accepted: 15-06-2021
}

\begin{abstract}
This study aims to analyze the influence of parental attention on students learning motivation in online learning during the covid-19 pandemic. The research method uses a quantitative approach. As many as 30 madrasah Tsanawiyah children aged 13-16 years were sampled in the study, they were given 20 questions related to learning motivation and parental attention. The selection of samples was conducted randomly in the pabuaran subdistrict of Serang Regency, Banten Province in 2021. This study uses descriptive quantitative methods. Research instruments using questionnaires through Google Form. The data analysis method is done with the belp of a computer software application program, SPSS 25 for windows. From the results of the data analysis known regression equation $Y=11.075+0.696$. While the results of the $T$ test obtained the results of the provisions of the Jubilee for $d f=28$ with an error rate of 0.05 or $5 \%$ is 1,701. While Thitung obtained from this study showed a value of 4,140. Because Thitung $>$ Ttabel $=4,140>1,701$ ha was accepted and $\mathrm{HO}$ was rejected. And the results of the calculation of determination test obtained the number $R^{2}$ ( $R$ Square) of 0.380 or $38 \%$. This indicates that the percentage influence of independent variables affects dependent variables by $38 \%$ while the rest by (100$38 \%=62 \%$ ) influenced by other variables or indicators not studied in this study. Thus, the results of the study concluded the influence of parental attention to the motivation of learning madrasah Tsanawiyah students in the district pabuaran Serang Banten Province. This study recommends parents to pay more attention to the child so that the child's learning motivation increases.
\end{abstract}

Keywords: Parent Attention, Learning Motivation, Online Learning

How to Cite Maptuhah, M., \& Juhji, J. (2021). Pengaruh Perhatian Orangtua dalam Pembelajaran daring terhadap Motivasi Belajar Peserta Didik Madrasah Tsanawiyah. Attadrib: Jurnal Pendidikan Guru Madrasah Ibtidaiyah, 4(1), 25-74. doi:

\section{PENDAHULUAN}

Dalam Pasal 1 Undang-Undang SISDIKNAS No. 20 Tahun 2003 menyebutkan bahwa Sistem pendidikan nasional adalah keseluruhan komponen pendidikan yang saling terkait secara terpadu untuk mencapai tujuan pendidikan nasional (Undang-Undang Sisdiknas, 2003). Menurut Soetarno (2003), pendidikan adalah sistem dengan suatu totalitas struktur yang terdiri dari beberapa komponen yang memiiki hubungan dan selalu berusaha menuju kepada tercapainya tujuan. Pendidikan merupakan sesuatu yang sangat penting bagi manusia kecil hingga orang tua. Hal ini disabdakan oleh Rasulullah Saw bahwa: tuntutlah ilmu sejak dari buaian hingga liang lahat (Safi'i, 2019). Iswati (2020) menyebutnya sebagai long life education. Pendidikan mempunyai peran yang begitu penting bagi kita karena dapat mendorong perkembangan individu setiap manusia disegala aspek kepribadian dan kehidupan. Pendidikan juga digunakan sebagai suatu indikator kemajuan bagi bangsa sehingga penting dalam mendukung adanya pembangunan, serta menjadi pondasi kompentensi bangsa. Dengan pendidikan manusia mampu menghadapi, memecahkan masalah dan tantangan yang dihadapinya. Oleh karena itu, pendidikan tidak bisa dipisahkan dari 
usaha-usaha yang harus dilakukan dalam menciptakan sumber daya manusia yang berkualitas dan kompeten.

Di dalam lingkugan keluarga terdapat orang tua yang memiliki tanggung jawab dalam pendidikan keapada anak (Jailani, 2014; Hasbullah, 2018). Orang tua adalah individu yang mengemban tanggung jawab terhadap satu keluarga (rumah tangga), yang dalam menghidupi kebutuhah sehari-hari lazim disebut ibu bapak (Hulukati, 2015). Keluarga sebagai pusat pendidikan pertama dan paling utama bagi anak dalam mendapatkan pendidikan (Mizal, 2014). Oleh karena itu, situasi serta kondisi di dalam suatu keluarga selalu mempengaruhi segala proses perkembangan anak menuju arah kematangan dan kedewasaan (Djaelani, 2013). Ada banyak yang bersumber dari keluarga mampu menimbulkan suatu perbedaan pada tiap individual, contohnya kultur atau budaya di dalam keluarga, sikap keluarga menghadapi masalah-masalah sosial, tingkat pendidikan orang tua, realitas pada kehidupannya, dan lain-lain. Perbedaan tersebut memiliki pengaruh besar terhadap tingkah laku dan perilaku belajar anak di sekolah.

Saat ini, beberapa penelitian melaporkan adanya pengaruh perhatian orang tua terhadap motivasi belajar anak-anak mereka (Alfiani, 2009; Nur, 2016; Vinorita \& Muhsin, 2018; Setiani et al., 2019). Saputri dan Siswanto (2019) menjelaskan bahwa perhatian orang tua merupakan suatu aktivitas yang tertuju pada suatu hal. Dalam hal ini, sesuatu tersebut adalah aktivitas seorang anak dalam belajar yang dilakukan oleh orang tuanya. Orang tua terdiri dari bapak dan ibu atau wali keluarga yang memiliki tanggung jawab atas pendidikan anak tersebut, seperti kasih sayang dan materi haruslah diberikan secara seimbang oleh orang tua kepada anaknya. Orang tua yang memiliki peran sebagai pendidik serta pembimbing bertanggung jawab dalam memperhatikan aktivitas belajar anak di rumah. Sebagai orang tua sudah pasti ingin anaknya dapat tumbuh, berkembang, pintar dan cerdas. Oleh karena itu demi mencapai hal tersebut, kedua orang tua merupakan berperan menjadi faktor yang sangat penting. Namun, berdasarkan hasil sebuah riset menyatakan bahwa orang tua yang begitu sibuk pada pekerjaannya hingga lupa kemudian tidak memikirkan perannya dalam mendidik anak, bahkan ada orang tua yang benar-benar tidak memahami serta menyadari perannya dan mereka cenderung menganggap tugas pendidikan anak sepenuhnya diserahkan kepada guru di sekolah (Khalimah, 2020).

Slameto (2010) yang mengatakan bahwa orang tua yang kurang ataupun tidak memperhatikan pendidikan anaknya, contohnya mereka kurang peduli terhadap belajar anaknya, tidak memperhatikan samasekali. Kebutuhan dan kepentingan anaknya dalam belajar, misalnya tidak mengatur waktu untuk anaknya belajar, tidak mempedulikan apakah anaknya belajar atau tidak, tidak menyediakan serta melengkapi kebutuhan alat belajarnya, tidak mau tau apakah ada kemajuan belajar anaknya, adakah berbagai kesulitan yang dirasakan anaknya dalam belajar dan lain-lain. Hal tersebut dapat menyebabkan anak kurang atau tidak termotivasi dalam kegiatan belajarnya. Perhatian adalah suatu hal yang begitu penting diperlukan oleh seorang anak karena perhatian orang tua memiliki peran pada perkembangan dan pertumbuhan anak (Slameto, 2010). Perhatian orang tua sangat dibutuhkan sebagai penguatan pada proses pembelajaran anak, perhatian tersebut dapat dilakukan dengan berbagai cara, misalnya mendampingi anak pada saat belajar di rumah, menentukan jam belajar anak di rumah serta bertanya pada anak tentang kegiatan belajarnya. Dengan adanya perhatian tersebut tentunya akan meninggalkan kesan pada anak sehingga anak akan lebih semangat dalam belajar. Akan tetapi, perhatian yang terlalu disiplin bukanlah hal yang baik untuk diterapkan dalam membingbing anak belajar karena dapat menimbulkan sikap yang berontak pada anak karena akan merasa terbebani atau tertekan dan tidak dapat mengungkapkan pendapatnya.

Tugas yang paling utama anak di sekolah yaitu belajar, kemudian dukungan sangat mendasar yang dibutuhkan oleh sekolah dari orangtuanya adalah mendukung proses pembelajaran anak-anak, yaitu belajar untuk melakukan hal terbaik yang mampu dilakukan (Lickona, 2013). Tugas anak yang utama adalah belajar serta memahami materi pelajaran yang diajarkan oleh guru. Salah satu tugas utama siswa yaitu perlu adanya motivasi dalam mengikuti proses pembelajaran. 
Motivasi tidak sebatas dipengaruhi oleh kegiatan pembelajaran yang ada di sekolah saja, akan tetapi lingkungan sekitar juga ikut mempengaruhi. Lingkungan sekitar tersebut menurut Slameto (2010) yaitu faktor lingkungan keluarga, lingkungan sekolah dan lingkungan masyarakat yang mana mempengaruhi motivasi belajar anak. Dari ketiganya, faktor yang memiliki pengaruh kuat terhadap motivasi belajar siswa dan pengaruh yang paling besar yaitu dari lingkungan keluarga.

Belajar merupakan suatu proses yang komplek yang terjadi pada setiap individu dan berlangsung seumur hidup mulai dia masih bayi sampai ke liang lahat (Juhji, 2015; Suardi, 2018; Rendi, 2019). Sedangkan menurut Subini (2013), belajar merupakan suatu perubahan dalam diri individu yang terjadi karena adanya suatu pengalaman. Belajar adalah suatu aktivitas yang paling banyak dilakukan oleh orang. Baharuddin (2009) menyatakan bahwa belajar bisa dilakukan hampir setiap waktu, kapan saja, di mana saja, serta sedang melakukan apa saja, seperti sekolah, di jalan, di rumah, baik sedang bekerja, bermain atau lain sebagainya. Beberapa penelitian melaporkan adanya pengaruh motivasi belajar terhadap prestasi belajar (Hamdu \& Agustina, 2011; Asvio, 2017; Tokan \& Imakulata, 2019), hasil belajar (Taurina, 2015; Alhadi \& Saputra, 2017; Lestari, 2017), dan kecakapan hidup siswa (Kiswoyowati, 2011). Namun, beberapa penelitian yang lainnya melaporkan adanya faktor-faktor lain yang mempengaruhi hasil belajar seperti penggunaan model pembelajaran (Febriati et al., 2019; Hujaemah et al., 2019), strategi pembelajaran (Nugralia et al., 2019), metode pembelajaran (Herawati et al., 2019; Mu'izzuddin et al., 2019; Tusaroh \& Juhji, 2020), dan media pembelajaran (Septantiningtyas et al., 2021; Syaepudin \& Juhji, 2020).

Menurut Mc. Donald dalam Sardiman (2012) disebutkan bahwa motivasi merupakan perubahan suatu energi pada diri seseorang yang ada ketika munculnya feeling dan terdapat tanggapan yang mendahului tanggapan terhadap adanya suatu tujuan. Motivasi merupakan suatu yang mendorong dari dalam seseorang untuk memunculkan suatu tindakan melalui cara-cara tertentu sesuai tujuan yang telah direncanakan (Kompri, 2017). Motivasi adalah pada diri siswa ada kekuatan di mental yang berperan sebagai penggerak untuk aktivitas belajar. Sumber dari kekuatan penggerak tersebut berasal dari berbagai hal, dalam peristiwa pertama, motivasi siswa yang rendah berubah menjadi lebih baik ketika siswa mendapatkan informasi yang benar. Dalam peristiwa kedua, suatu motivasi belajar bisa berubah rendah serta bisa diperbaiki lagi. Dalam peristiwa yang kedua tersebut peranan orang tua untuk meningkatkan motivasi belajar anak sangat berarti. Anak belajar karena distimulasi oleh kekuatan di mentalnya. Kekuatan mental tersebut berupa perhatian, keinginan, kemauan, atau cita-cita (Mudjiono, 2009). Dorongan yang timbul dari tujuan yang ada pada diri anak merupakan kekuatan mental yang selalu berorientasi pada pencapaian tujuan. Contohnya anak ingin sekali memperoleh peringkat pertama di sekolah akan tetapi nilai ulangan yang dia dapat selalu rendah. Anak tersebut menyadari bahwa hasil belajarnya masih tergolong rendah, sedangkan yang dia inginkan adalah menjadi peringkat di sekolah, maka akan muncul adanya dorongan untuk belajar dengan lebih giat lagi atau dengan mengambil kursus tambahan/les agar mampu meraih hasil belajar yang diinginkan. Pemberian motivasi yang tepat pada anak akan sangat mendukung semangat proses belajar serta memberikan dorongan pada anak untuk meraih hasil belajar yang optimal. Akan tetapi, perhatian yang terlalu menjunjung kedisiplinan yang berlebihan (overdiclipline) juga merupakan bukan hal yang baik apabila diterapkan di dalam keluarga karena akan menyebabkan sikap berontak oleh anak karena merasa tertekan serta tidak dapat mengungkapkan pendapat anak tersebut. Apalagi perhatian pada anak yang bersifat acuh tak acuh (rejection) atau tidak memilki kepedulian kegiatan belajar anaknya, kebutuhan anak tersebut dan lainlain. Apabila orang tua bersikap acuh tak acuh pada anaknya, anak akan merasa tidak ada yang peduli dalam keluarga dan anak cenderung menjadi pendiam serta sulit bergaul dengan lingkungan sekitarnya, selain itu akan menimbulkan rasa malas dalam kegiatan belajar. Pola asuh yang sepertu itu tidak diharapkan untuk diterapkan dalam suatu keluarga, sebab akan memberikan dampak tidak baik untuk anak-anak (Mawarsih \& Hamidi, 2013).

Seiring adanya kemajuan teknologi informasi dan komunikasi, saat ini pendekatan pembelajaran sudah berubah menuju arah pembelajaran abad pengetahuan (Supardi et al., 2021). 
Setiap orang dapat belajar kapan saja, di mana saja, dan dengan siapa saja. Seperti itulah ciri pembelajaran abad pengetahuan yang sudah dikenal sebagai berbasis komputer (Kuntarto, 2017). Teknologi internet juga mempunyai dampak terhadap perilaku serta kehidupan generasi masa kini. Saat ini Anak-anak sudah begitu akrab dengan dunia internet lewat berbagai perangkat gawai, misalnya: tablet; komputer; smartphone; laptop; handphone; dan perangkat sejenis lainnya. Namun hal yang begitu disayangkan yaitu adanya internet masih begitu kecil penggunaannya untuk kebutuhan pembelajaran (Chalim, 2018).

Orang tua hendaknya memperhatikan dan membimbing anak dalam penggunaan media internet ini, agar anak tidak merasa ketergantungan terhadap internet serta akan memiliki dampak negatif untuk perilaku dan sikap anak. Orang tua harus mengarahkan anak untuk memanfaatkan internet secara positif, seperti untuk pendidikan serta memperluas ilmu pengetahuan. Orang tua mengarahkan kepada anak untuk membuka berbagai situs yang bermanfaat, misalnya untuk mengerjakan berbagai tugas dari ssekolah melalui pemanfaatan internet, memahami berbagai aplikasi yang mendidik anak, memandu anak untuk menggunakannya dengan baik, kemudian mengawasi penggunaan bebagai media informasi tersebut supaya tidak mengalami penyimpangan. Selanjutnya, orang tua harus memberikan batasan waktu dalam penggunaan internet, akan tetapi mengontrol penggunaan internet tidak perlu dilakukan secara ketat. Mengawasi perlu diterapkan dengan cara persuatif akan tetapi tetap menghargai privacy pada anak (Khairani, 2019).

Melihat kasus pandemi akibat Covid-19 saat ini pemerintah telah merubah kegiatan pembelajaran dari sekolah dialihkan ke rumah masing-masing siswa sebagai salah satu dari upaya menghentikan penyebaran Covid-19 dengan penerapan kurikulum darurat (Juhji et al., 2021). Akan tetapi, agar tidak disalah-artikan oleh siswa sebagai hari libur, maka proses aktivitas pembelajaran dilaksanakan secara daring (online). Perubahan pola pembelajaran di semua jenjang pendidikan akibat pandemi Covid-19, mengakibatkan pembelajaran tidak dapat dilakukan dengan tatap muka atau secara langsung antar guru dan siswa di kelas. Oleh karena itu pembelajaran tatap muka digantikan dengan sistem pembelajaran yang terintegrasi melalui jaringan internet (online learning) (Harefa \& Hia, 2020).

Terkait dengan fenomena pada Madrasah Tsanawiyah di Kecamatan Pabuaran Kabupaten Serang Provinsi Banten, berdasarkan hasil pra riset, orang tua yang terlalu sibuk dengan pekerjaannya baik itu di luar atau di dalam rumah, sehingga lupa dan tidak memperhatikan anaknya dalam belajar, atau orang tua yang samasekali tidak memahami dan betapa pentingnya perhatian orang tua terhadap motivasi belajar anak dalam pembelajaran daring saat ini. Berkaitan dengan adanya perhatian orang tua yang sangat penting, sehingga seharusnya orang tua lebih dituntut agar selalu meluangkan waktu lebih untuk memperhatikan pendidikan pada anak. Oleh karena itu, berdasarkan latar belakang yang telah dipaparkan di atas, tujuan penelitian ini adalah untuk menganalisis pengaruh perhatian orang tua terhadap motivasi belajar siswa dalam pembelajaran daring.

\section{METODE}

Penelitian ini menggunakan metode deskriptif kuantitatif. Sampel yang digunakan yaitu 30 orang dengan usia 13-16 tahun yang merupakan siswa Madrasah Tsanawiyah di Kecamatan Pabuaran Kabupaten Serang Provinsi Banten. Tiga puluh anak yang sedang belajar di tingkat Madrasah Tsanawiyah yang terdiri atas 8 siswa laki-laki (26\%) dan 22 siswa perempuan (73,3\%) diberikan pertanyaan melalui Google Form seperti ditunjukan dalam Tabel 1.

Tabel 1 Informasi Demografi Siswa

\begin{tabular}{|c|c|c|c|}
\hline \multicolumn{2}{|c|}{ Informasi } & Frekuensi & $\%$ \\
\hline Jenis Kelamin & Laki-laki & 8 & 26,7 \\
\hline & Perempuan & 22 & 73,3 \\
\hline Usia & 13 tahun & 4 & 13,3 \\
\hline
\end{tabular}




$\begin{array}{cccc} & 14 \text { tahun } & 6 & 20 \\ 15 \text { tahun } & 15 & 50 \\ 16 \text { tahun } & 5 & 16,7 \\ \text { Kelas } & 7 & 4 & 13,3 \\ & 8 & 8 & 26,7 \\ & 9 & 18 & 60\end{array}$

Variasi usia responden terlihat pada rentang 13 sampai 16 tahun, sengan rincian yang berusia13 tahun sebanyak 4 orang (13,3\%), usia 14 tahun sebanyak 6 orang $20 \%$ ), usia 15 tahun sebanyak 15 orang (15\%), usia 16 tahun sebanyak 5 orang (16,7\%). Frekuensi usia terbanyak (modus) berada pada usia 15 tahun (50\%) dan frekuensi usia terendah berada pada usia 13 tahun (13.3\%). Mereka diberikan beberapa pertanyaan dan jumlah pertanyaan yang sama terkait dengan perhatian orang tua dan motivasi belajar selama pembelajaran daring masa pandemi Covid-19.

Instrumen penelitian menngunakan angket melalui Google Form. Satu variabel bebas yakni Perhatian orang tua serta satu variabel terikat yakni motivasi belajar. Metode analisis data dilakukan dengan bantuan program aplikasi software komputer yaitu SPSS 25 for windows, menggunakan analisis regresi linear sederhana, serta skala pengukuran dengan skala Likert, uji t, dan koefisien determinasi. Berikut merupakan hasil rentang skala interval yang digunakan (Tabel 2).

Tabel 2 Skor Hasil Penelitian

\begin{tabular}{c|c}
\hline Bobot Nilai & Jawaban Responden \\
\hline 5 & Selalu \\
4 & Sering \\
3 & Kadang-kadang \\
2 & Pernah \\
1 & Tidak Penah \\
\hline
\end{tabular}

\section{HASIL DAN PEMBAHASAN}

\section{Hasil}

Penelitian ini menggunakan 20 item pertanyaan untuk mengukur variabel perhatian orang tua dan variabel motivasi belajar. Hasil angket ditabulasi untuk mengubah data dan instrumen pengumpul data (angket) menjadi tabel angka. Skala yang digunakan untuk menganalisis data yakni skala Likert dengan klasifikasi penilaian skor: 5) Selalu; 4) Sering; 3) Kadang-kadang; 2) Pernah; 1) Tidak Pernah. Berdasarkan pada hasil jawaban 30 responden pada indikator perhatian orang tua (variabel $\mathrm{X}$ ) yang memiliki rata-rata tertinggi yaitu memperhatikan kondisi kesehatan anak dalam belajar sebesar 4,6. Hal ini berarti bahwa perhatian orang tua terlihat sangat baik dan positif yang dapat membangun semangat siswa dalam belajar, dimana pernyataan ketiga "Ketika sedang sakit, orang tua merawat saya dengan baik, agar lekas sembuh dan bisa kembali mengikuti pelajaran daring" memiliki nilai terbesar yaitu sebesar 4,73. Hal ini menunjukan bahwa indikator ini dikategorikan sangat baik.

Berasarkan pada hasil jawaban 30 responden pada indikator motivasi belajar (variabel Y) yang memiliki rata-rata tertinggi yaitu tekun dalam mengerjakan tugas sebesar 4,18. Hal tersebut menunjukan bahwa motivasi belajar terlihat sangat baik dan positif yang dapat membangun semangat siswa dalam belajar, dimana pernyataan kedua "Dalam mengerjakan tugas belajar daring, saya selalu bersungguh-sungguh" memiliki nilai terbesar yaitu sebesar 4,43. Hal ini menunjukan bahwa indikator ini dikategorikan sangat baik.

\section{Analisis Regresi Linear Sederhana}


Pada Tabel 3 menggambarkan besaran koefisien regresi menunjukan nilai $\mathrm{a}=$ angka konstan dari koefisien. Dalam hal ini nilainya sebesar 11,075, angka ini adalah angka konstan yang memiliki arti bahwa jika tidak ada perhatian orang tua $(\mathrm{X})$ maka nilai konsisten motivasi belajar (Y) adalah sebesar 11,075. b = angka koefisien regresi, nilainya sebesar 0,696. Angka ini mengandung arti bahwa apabila ada penambahan $1 \%$ tingkat perhatian orang tua (X) maka motivasi belajar $(\mathrm{Y})$ akan meningkat sebesar 0,696 . Sehingga persamaan regresi linearnya adalah $\mathrm{Y}$ $=11,075+0,696$.

Tabel 3 Regresi Linear Sederhana

\begin{tabular}{|c|c|c|c|c|c|c|}
\hline \multicolumn{7}{|c|}{ Coefficients $^{a}$} \\
\hline \multirow[b]{2}{*}{ Model } & & \multicolumn{2}{|c|}{ Unstandardized Coefficients } & \multirow{2}{*}{$\begin{array}{c}\text { Standardized } \\
\text { Coefficients } \\
\text { Beta } \\
\end{array}$} & \multirow[b]{2}{*}{$\mathrm{T}$} & \multirow[b]{2}{*}{ Sig. } \\
\hline & & B & Std. Error & & & \\
\hline \multirow[t]{2}{*}{1} & (Constant) & 11,075 & 7,171 & & 1,544 & ,134 \\
\hline & Perhatian Orang Tua & ,696 & ,168 & ,616 & 4,140 & 000 \\
\hline
\end{tabular}

a. Dependent Variable: Motivasi Belajar

Variabel perhatian orang tua merupakan variabel yang mempunyai pengaruh pada motivasi belajar siswa, dinyatakan bahwa jika tidak ada perhatian orang tua, konsisten motivasi belajar $(\mathrm{Y})$ adalah sebesar 11,075. Jika penambahan 1 perhatian orang tua maka motivasi belajar akan meningkat sebesar 0,696. Begitupun sebaliknya, jika penurunan 1 perhatian orang tua maka motivasi belajar akan mengalami penurunan sebesar 0,696.

\section{Uji Koefisien Parsial (Uji t)}

Hasil uji koefisien parsial (uji t) dapat dilihat pada Tabel 4 berikut ini:

Tabel 4 Regresi Linear Sederhana

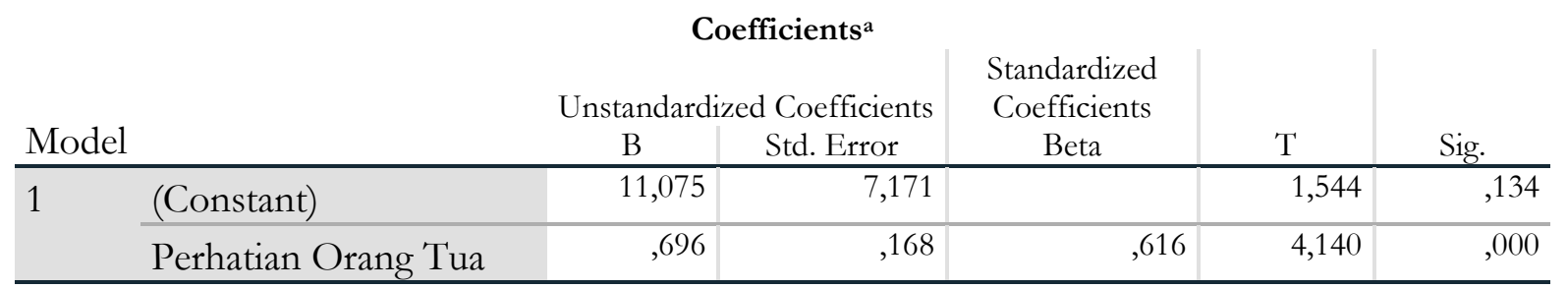

a. Dependent Variable: Motivasi Belajar

Berdasarkan tabel 4 diatas adanya pengaruh perhatian orang tua terhadap motivasi belajar siswa pada masa pandemi COVID-19 dengan ketentuan Ttabel untuk $\mathrm{df}=\mathrm{N}-2=30-2=28$ dengan tingkat kesalahan 0,05 atau $5 \%$ adalah 1,701. Sedangkan Thitung yang didapat dari penelitian ini menunjukan nilai 4,140 maka Ha diterima dan Ho ditolak.

\section{Koefisien Determinasi}

Hasil uji koefisien determinasi dapat dilihat pada tabel 5 berikut ini:

Tabel 5 Hasil Uji Determinasi

\begin{tabular}{cc|c|c|c} 
& & \multicolumn{4}{c}{ Model Summary } \\
Model & $\mathrm{R}$ & R Square & $\begin{array}{c}\text { Adjusted R } \\
\text { Square }\end{array}$ & Std. Error of the Estimate \\
\hline 1 &, $616^{\mathrm{a}}$ &, 380 &, 357 & 5,817 \\
\hline a. Predictors: (Constant), Perhatian Orang Tua
\end{tabular}

a. Predictors: (Constant), Perhatian Orang Tua

Pada tabel 5 diperoleh angka $\mathrm{R}^{2}$ (R Square) sebesar 0,380 atau 38\%. Hal ini menunjukan bahwa persentase pengaruh variabel independen mempengaruhi variabel dependen sebesar 38\% 
sedangkan sisanya sebesar $(100-38 \%=62 \%)$ dipengaruhi oleh variabel atau indikator lain yang tidak diteliti dalam peneltian ini.

\section{Pembahasan}

Dari hasil penelitian ini dapat diungkapkan bahwa sebagian besar siswa Madrasah Tsanawiyah wilayah Kecamatan Pabuaran Kabupaten Serang Provinsi Banten Rancalutung berpendapat bahwa perhatian orang tua di Madrasah Tsanawiyah wilayah Kecamatan Pabuaran Kabupaten Serang Provinsi Banten dapat dikategorikan pada kondisi baik dengan presentase sebesar 38\%. Penelitian ini juga membuktikan bahwa hipotesis diterima, yaitu perhatian orang tua siswa di Madrasah Tsanawiyah wilayah Kecamatan Pabuaran Kabupaten Serang Provinsi Banten berpengaruh positif dan signifikan terhadap motivasi belajar. Hal ini ditunjukan dengan nilai koefisien regresi yang positif dan nilai signifikansi kurang dari 0,05 .

Oleh karena itu apabila Madrasah Tsnawiyah wilayah Kecamatan Pabuaran Kabupaten Serang Provinsi Banten ingin meningkatan motivasi belajar siswanya, maka perhatian orang tua dari siswa harus lebih ditingkatkan. Hasil ini mendukung teori yang dijelaskan oleh Agus Suprijono (Suprijono, 2013) bahwa dalam lingkungan keluarga yang mana kedua orang tuanya sibuk untuk bekerja dari pagi sampai sore hari kemudian sampai di rumah mereka merasa lelah dan menyebabkan kurang memperhatikan anaknya, baik pada kehidupan dalam rumah ataupun pada perkembangan pendidikan anak di sekolah sehingga akan menghambat motivasi belajar anak. Dengan demikian, maka kesibukan orang tua adalah salah satu dari faktor penghambat motivasi belajar pada siswa di sekolah. Hasil pada penelitian ini juga didukung penelitian yang sudah dilakukan oleh Afriansyah. Dalam penelitian tersebut menyimpulkan bahwa perhatian orang tua secara parsial memiliki pengaruh positif serta signifikan terhadap motivasi belajar siswa. Sehingga hasil penelitian ini mendukung hasil penelitian yang dilakukan sebelumnya (Afpriansyah, 2020).

Perhatian orang tua memiliki pengaruh terhadap motivasi belajar siswa dalam kegiatan belajarnya, dengan demikian hal tersebut akan menentukan berhasil tidaknya kegiatan belajar siswa. Oleh sebab itu, penting sekali bagi orang tua untuk memberikan perhatian kepada siswa, karena akan membantu untuk meningkatkan motivasi belajar pada siswa dalam belajar, supaya siswa memperoleh hasil belajar secara optimal. Sependapat dengan Sardiman yang mengatakan bahwa motivasi belajar merupakan suatu daya upaya, penggerak yang menjadi pendorong seseorang untuk melakukan suatu aktivitas belajar demi mencapai suatu tujuan yang diharapkan (Sardiman, 2012). Menurut Dalyono, terdapat dua faktor yang mempengaruhi motivasi belajar yaitu faktor internal yang terdiri dari kesehatan, cara belajar, intelegensi, minat, bakat, dan motivasi. Dari faktor eksternal terdiri dari keluarga, sekolah, lingkungan sekolah, masyarakat. Pada penelitian ini perhatian orang tua merupakan faktor eksternal karena selain faktor yang ada di dalam diri siswa itu sendiri, faktor yang memiliki pengaruh motivasi belajar juga berasal dari luar diri siswa yaitu perhatian dari orang tuanya. Didasarkan atas perhatian orang tua yang memiliki pengaruh terhadap motivasi belajar tersebut, maka sudah seharusnya orag tua meningkatkan perhatiannya, dan sebaiknya untuk tetap mengarahkan dan melakukan paengontrolan terhadap perilaku siswa, menjalin komunikasi yang baik, memberihan nasehat, dan seterusnya, dengan hal tesebut akan membuat siswa merasa kasih sayang serta merasa diperhatikan sehingga motivasi belajar pada siswa akan meningkat (Rusliandi, 2014).

\section{KESIMPULAN}

Berdasarkan pembahasan dan hasil penelitian yang dilakukan di wilayah Kecamatan Pabuaran Kabupaten Serang Provinsi Banten bahwa perhatian orang tua terhadap motivasi belajar siswa memiliki pengaruh positif sebesar 38\%. Berdasarkan uji t tadi diperoleh nilai sebesar 
Thitung $=4,140>$ Ttabel $=1,701$ artinys lebih besar dari Ttabel. Dan nilai signifikansi $0,000<$ 0,05 artinya nilai signifikansinya lebih kecil dari 0,05 sehingga dalam penelitian ini hipotesis alternatif Ha diterima dan Ho ditolak. Maka dapat disimpulkan bahwa terdapat pengaruh dari perhatian orang tua terhadap motivasi belajar siswa. Artinya jika orang tua memberikan perhatian lebih banyak pada siswa maka akan semakin meningkat pula motivasi belajar siswa. Sebaliknya jika orang tua kurang memberikan perhatian pada siswa maka akan kurang juga motivasi belajar siswa.

\section{BIBLIOGRAPHY}

Afpriansyah, P. (2020). Pengaruh Perhatian Orang Tua Terhadap Motivasi Belajar Siswa Kelas VIII di SMP Negeri 13 Palembang. UIN Raden Fatah Palembang.

Alfiani, S. (2009). Pengaruh perhatian dan latar belakang ekonomi orang tua terhadap motivasi belajar siswa SMA Negeri 6 Malang [Skripsi]. Universitas Negeri Malang.

Alhadi, S., \& Saputra, W. N. E. (2017). The Relationship Between Learning Motivation and Learning Outcome of Junior High School Students in Yogyakarta. 1st Yogyakarta International Conference on Educational Management/Administration and Pedagogy (YICEMAP 2017).

Asvio, N. (2017). The Influence of Learning Motivation and Learning Environment on Undergraduate Studentsâ $€^{\mathrm{TM}}$ Learning Achievement of Management of Islamic Education, Study Program of Iain Batusangkar In 2016. Noble International Journal of Social Sciences Research, 2(2), 16-31.

Baharuddin. (2009). Pendidikan dan Psikologi Perkembangan. Ar-Ruzz Media.

Chalim, S. (2018). Peran Orang tua dan Guru dalam Membangun Internet sebagai Sumber Pembelajaran (The Role of Parents and Teachers in Building the Internet as a Source of Learning). 14, 43.

Djaelani, M. S. (2013). Peran pendidikan agama Islam dalam keluarga dan masyarakat. Jumal Ilmiah Widya, 1(2), 100-105.

Febriati, Y., Saefurohman, A., \& Juhji, J. (2019). Efektivitas Penerapan Model Children Learning in Science terhadap Pemahaman Konsep IPA. Ibtida'i: Jurnal Kependidikan Dasar, 6(1), 2940 .

Hamdu, G., \& Agustina, L. (2011). Pengaruh motivasi belajar siswa terhadap prestasi belajar IPA di sekolah dasar. Jurnal Penelitian Pendidikean, 12(1), 90-96.

Harefa, S., \& Hia, Y. (2020). Pengaruh Perhatian Orang Tua dalam Pembelajaran Online Matematika Terhadap Motivasi Belajar Siswa. Jurnal Fibonaci, 1, 1.

Hasbullah, H. (2018). Lingkungan pendidikan dalam al-qur'an dan hadis. Tarbawi: Jurnal Keilmuan Manajemen Pendidikan, 4(01), 13-26.

Herawati, L., Saefurohman, A., \& Juhji, J. (2019). Pengaruh Metode Eksperimen Terhadap Pemahaman Konsep Siswa MI Pada Materi Sifat dan Perubahan Wujud Benda. Primary: Jurnal Keilmuan Dan Kependidikan Dasar, 11(01), 69-76.

Hujaemah, E., Saefurrohman, A., \& Juhji, J. (2019). Pengaruh penerapan model snowball throwing terhadap hasil belajar ipa di sekolah dasar. Muallimuna: Jurnal Madrasah Ibtidaiyah, $5(1), 23-32$.

Hulukati, W. (2015). Peran lingkungan keluarga terhadap perkembangan anak. Jurnal Musawa IAIN Palu, 7(2), 265-282. 
Iswati, I. (2020). Long Life Eduction Dalam Perspektif Hadits (suatu Tinjauan Pendidikan Sejak Pranatal Dan Analisis Terhadap Kualitas Hadits Pendidikan Sepanjang Hayat). At-Tajdid: Jurnal Pendidikan Dan Pemikiran Islam, 3(2), 126-147.

Jailani, M. S. (2014). Teori Pendidikan Keluarga dan Tanggung Jawab Orang Tua dalam Pendidikan Anak Usia Dini. Nadwa, 8(2), 245-260.

Juhji, J. (2015). Telaah Komparasi Konsep Pembelajaran menurut Imam Al-Zarnuji dan Imam Al-Ghozali. Tarbawi: Jurnal Keilmuan Manajemen Pendidikan, 1(02), 17-26.

Juhji, J., Latar, B., Tarihoran, W. S., \& Maman, M. (2021). Strengthening Islamic Education Management Through Emergency Curriculum Adaptation During the Covid-19 Pandemic. International Journal of Instruction, Technology, and Social Sciences, 1(3), 1-7.

Khairani, W. (2019). Peran Orang tua Terhadap Penggunan Media Internet Dalam Perilaku Keagamaan Anak (Studi pada Keluarga Muslim di Kelurahan Bandar Jaya Barat Kecamatan Terbanggi Besar). UIN Raden Intan Lampung.

Khalimah, S. N. (2020). Peran Orang Tua dalam Pembelajaran Daring di MI Darul Ulum Pedurungan Kota Semarang Tahun Pelajaran 2020/2021. 5.

Kiswoyowati, A. (2011). Pengaruh Motivasi Belajar Dan Kegiatan Belajar Siswa Terhadap Kecakapan Hidup Siswa. Portal Jurnal Universitas Pendidikan Indonesia, 2(1), 12-16.

Kompri. (2017). Belajar Faktor-faktor yang Memperngarubinya. Media Akademi.

Kuntarto, E. (2017). Keefektifan Model Pembelajaran Daring Dalam Perkuliahan Bahasa Indonesia di Perguruan Tinggi. 3, 99.

Lestari, W. (2017). Pengaruh kemampuan awal matematika dan motivasi belajar terhadap hasil belajar matematika. Jurnal Analisa, 3(1), 76-84.

Lickona, T. (2013). Pendidikan Karakter: Panduan Lengkap Mendidik Siswa Menjadi Pintar dan Baik. Penerbit Nusa Media.

Mawarsih, S. E., \& Hamidi, N. (2013). Pengaruh Perhatian Orang Tua dan Motivasi Belajar terhadap Prestasi Belajar Siswa SMA Negeri Jumapolo. JUPE UNS, 1, 6.

Mizal, B. (2014). Pendidikan dalam keluarga. Jurnal Ilmiah Peuradeun, 2(3), 155-178.

Mudjiono, D. (2009). Belajar dan Pembelajaran. Rineka Cipta.

Mu'izzuddin, M., Juhji, J., \& Hasbullah, H. (2019). Implementasi metode sorogan dan bandungan dalam meningkatkan kemampuan membaca kitab kuning. Geneologi PAI: Jurnal Ilmiah Bidang Pendidikan Agama Islam, 6(1), 43-50.

Nugralia, S., Habudin, H., \& Juhji, J. (2019). Pengaruh Penggunaan Strategi Card Sort terhadap Hasil Belajar IPA Materi Sumber Energi (Pre Eksperimen Siswa Kelas IV SD Negeri Kemang Kota Serang). Ibtida'i: Jurnal Kependidikan Dasar, 6(01), 79-94.

Nur, M. A. (2016). Pengaruh Perhatian Orang Tua, Konsep Diri, Persepsi Tentang Matematika Terhadap Hasil Belajar Matematika Melalui Motivasi Belajar Siswa Kelas VIII SMP Negeri Di Kecamatan Ujung Loe Kabupaten Bulukumba. Matematika Dan Pembelajaran, 4(2), 64-79.

Rendi, R. (2019). Pendidikan Sepanjang Hayat Dan Pendekatan Androgogi. An-Nidhom: Jurnal Manajemen Pendidikan Islam, 4(1), 108-121.

Rusliandi. (2014). Pengarub persepsi siswa tentang layanan bimbingan belajar terbadap motivasi belajar siswa semester II di SMK Negeri 1 Sampit. STKIP Muhammadiyah Sampit. 
Safi'i, I. (2019). Pendidikan Agama di Lingkungan Keluarga Guna Membangun Mentalitas Bangsa. Vicratina: Jurnal Pendidikan Islam, 2(2), 99-108.

Saputri, D. I., \& Siswanto, J. (2019). Pengaruh Perhatian Orang Tua dan Motivasi Terhadap Hasil Belajar. Jurnal Pedagogi dan Pembelajaran, 2(3), 370.

Sardiman. (2012). Interaksi dan Motivasi Belajar Mengajar. Rajawali Pers.

Septantiningtyas, N., Juhji, J., Sutarman, A., Rahman, A., \& Sa'adah, N. (2021). Implementation of Google Meet Application in the Learning of Basic Science in the Covid-19 Pandemic Period of Student Learning Interests. Journal of Physics: Conference Series, $1779(1), 012068$.

Setiani, F., Jayadi, J., \& Setyaningsih, S. (2019). Pengaruh Perhatian Orang Tua terhadap Motivasi Belajar Siswa Pada Sma Negeri 2 Sampit. Jurnal Paedagogie Media Kependidikan, Keilmuan Dan Keagamaan, 7(1), 48-55.

Sistem Pendidikan Nasional. (2003). In Undang-Undang Nomor 20 Tahun 2003.

Slameto. (2010). Belajar dan Faktor-faktor yang Mempengarubinya. Rineka Cipta.

Soetarno, N. (2003). Perpustakaan dan Masyarakat. Yayasan Obor Indonesia.

Suardi, M. (2018). Belajar \& pembelajaran. Deepublish.

Subini. (2013). Psikologi Pembelajaran. Mentari Pustaka.

Supardi, S., Juhji, J., Azkiyah, I., Muqdamien, B., Ansori, A., Kurniawan, I., \& Sari, A. F. (2021). The ICT basic skills: Contribution to student social media utilization activities. International Journal of Evaluation and Research in Education (IJERE), 10(1), 222-229.

Suprijono, A. (2013). Cooperative Learning. Pustaka Pelajar.

Syaepudin, S., \& Juhii, J. (2020). The Effect of Using Powerpoint Media on Student Learning Outcomes in the Material Adaptation of Living Things. Pedagogi: Jurnal Penelitian Pendidikan, 7(1).

Taurina, Z. (2015). Students' motivation and learning outcomes: Significant factors in internal study quality assurance system. International Journal for Cross-Disciplinary Subjects in Education (IJCDSE), 5(4), 2625-2630.

Tokan, M. K., \& Imakulata, M. M. (2019). The effect of motivation and learning behaviour on student achievement. South African Journal of Education, 39(1).

Tusaroh, A., \& Juhji, J. (2020). The Effect of Role-Playing Method on Student's Confidence in Indonesian Language Subjects. Madrosatuna: Journal of Islamic Elementary School, 4(1), 01-07.

Vinorita, D., \& Muhsin, M. (2018). Pengaruh Perhatian Orang Tua, Komunikasi Guru, Pemberian Reward, Dan Fasilitas Belajar Terhadap Motivasi Belajar. Economic Education Analysis Journal, 7(2), 553-567. 